Proc. Indian Acad. Sci. (Earth Planet. Sci.), Vol. 99, No. 1, March 1990, pp. 91-98.

C. Printed in India.

\title{
High pressure-temperature studies on an olivine tholeiite and a tholeiitic picrite from the pavagarh region, Gujarat, India
}

\author{
SNEHMANI AGRAWAL ${ }^{1}, M_{\text {M BINDAL }}^{2}$, and ALOK K GUPTA ${ }^{1}$ \\ ${ }^{1}$ Department of Earth and Planetary Sciences, University of Allahabad, Allahabad 211002 , \\ India \\ ${ }^{2}$ H.E.P.P. Division, National Physical Laboratory, New Delhi 110012, India
}

\begin{abstract}
Experimental studies have been performed on an olivine tholeiite and tholeiitic picrite at pressure and temperature ranges of $20-40 \mathrm{~kb}$ and $1200-1300^{\circ} \mathrm{C}$. The lower and upper limits of basalt-eclogite transition zone for tholeiitic picrite are $23 \mathrm{~kb}$ and $31.67 \mathrm{~kb}$ at $1200^{\circ} \mathrm{C}$, and $24.67 \mathrm{~kb}$ and $33.67 \mathrm{~kb}$ at $1300^{\circ} \mathrm{C}$, whereas for olivine tholeite, these are $27 \mathrm{~kb}$ and $32.33 \mathrm{~kb}$ at $1200^{\circ} \mathrm{C}$, and $28.70 \mathrm{~kb}$ and $33.70 \mathrm{~kb}$ at $1300^{\circ} \mathrm{C}$. While the assemblages for both samples below the transition region are $\mathrm{Pl}+\mathrm{Px}+\mathrm{Mt}$, they are $\mathrm{Pl}+\mathrm{Gt}+\mathrm{Px}+\mathrm{Mt}$ within it. The eclogite field has $\mathrm{Gt}+\mathrm{Px}+\mathrm{Mt}$. The ratio of garnet to plagioclase increases from the transition zone to the eclogite field and with the disappearance of plagioclase, the percentage of garnet increases to 30 in the eclogite field.

Comparison of our results wit' the transition zone found by us occurs at higher pressure-temperature conditions. Seismic studies of the region below the Deccan Traps show an increase in velocity (1-4\%) at depth. It is suggested that after partial melting, during ascent of the basaltic liquid, a significant portion of it crystallizes within the upper mantle as pockets of eclogite. As eclogite is more dense than peridotite, their presence should cause a similar increase in the seismic velocity below the Deccan area.
\end{abstract}

Keywords. High pressure-temperature studies; olivine tholeiite; tholeiitic picrite.

\section{Introduction}

Continental flood basalts, all over the world, are characterized by voluminous eruption within a geologically short time-span. They attracted the attention of field petrologists and consequently, a lot of petrological studies have been made.

The Deccan Traps (Cretaceous to Paleocene) of south-western India possibly constitute the most voluminous flood basalt province known, covering an area of more than $5 \cdot 10^{5} \mathrm{~km}^{2}$ (thickness: $1000 \mathrm{~m}$, locally $3000 \mathrm{~m}$ ). Numerous field studies have been conducted in this area during the past years. No systematic experimental study, however, has been made on Deccan basalts to understand their genesis. In recent years, a lot of seismic data about the structure of the lithosphere beneath the Deccan area have been reported by Iyer et al (1989) who noted a sudden increase in the seismic velocity $(1-4 \%)$ at depth.

The present experimental study was initiated to learn not only about the genesis of the Deccan basalts but also to propose a model which can explain the sudden increase in velocity within the upper mantle, particularly below the region of the basalts. 


\section{Experimental technique}

A 200-tonne cubic press designed by Tracy Hall, was used for the high pressure runs (for details of design, experimental technique and procedure, refer Singh et al 1990, this volume).

Two samples were collected from Pavagarh volcanic complex (Mukherjee 1986), which is located $40 \mathrm{~km} \mathrm{NE}$ of Vadodara in Panchmahal district of Gujarat (India). The complex comprises seventeen flows, eruption of which took place in two cycles. The present samples are representatives of the first (D-81) and seventh flows (D-159) of the first cycle.

Sample D-81 is a tholeiitic picrite (tables $1 \mathrm{a}, 1 \mathrm{~b}$ and $1 \mathrm{c}$ ) with numerous suspended olivine crystals. It is considered to approximate the composition of the parental liquid for the entire lava sequence. Its petrographic study shows that it is very coarse-grained and porphyritic. Olivine and two pyroxenes are present as phenocrysts along with plagioclase. Olivine has reaction relation with groundmass. Titano-magnetite is present as accessory microphenocrysts. Groundmass is rich in plagioclase, pyroxene and interstitial glass.

Sample D-159, an olivine-tholeiite (tables $1 \mathrm{~b}$ and 1c), is comparatively coarse-

Table 1a. Electron probe micro analyses of different minerals (Analyst: A K Gupta).

\begin{tabular}{|c|c|c|c|c|c|c|}
\hline \multirow{2}{*}{$\begin{array}{l}\text { Flow No. } 1 \\
\text { Sample No. D-81 }\end{array}$} & \multirow{2}{*}{$\begin{array}{c}\text { Plagioclase } \\
{ }^{1} \mathrm{mph}\end{array}$} & \multicolumn{3}{|c|}{ Pyroxene } & \multicolumn{2}{|c|}{ Oxide phases } \\
\hline & & 1 & 2 & 3 & ${ }^{1} \mathrm{mph}^{*}$ & ${ }^{2} \mathrm{mph} *$ \\
\hline $\mathrm{SiO}_{2}$ & $60 \cdot 43$ & $50 \cdot 34$ & $50 \cdot 41$ & 50.95 & $0 \cdot 19$ & - \\
\hline $\mathrm{TiO}_{2}$ & 0.21 & 1.40 & 1.03 & 1.41 & $29 \cdot 33$ & $29 \cdot 14$ \\
\hline $\mathrm{Al}_{2} \mathrm{O}_{3}$ & $23 \cdot 35$ & $2 \cdot 44$ & 6.98 & $2 \cdot 47$ & 1.83 & 1.65 \\
\hline $\mathrm{Cr}_{2} \mathrm{O}_{3}$ & - & $0 \cdot 24$ & 0.21 & $0 \cdot 24$ & - & $0 \cdot 17$ \\
\hline $\mathrm{FeO}$ & 0.32 & $8 \cdot 65$ & $8 \cdot 06$ & 8.76 & $62 \cdot 82^{*}$ & $63.01^{*}$ \\
\hline $\mathrm{MnO}$ & - & $0 \cdot 16$ & $0 \cdot 16$ & $0 \cdot 16$ & $1 \cdot 52$ & 1.54 \\
\hline $\mathrm{MgO}$ & 0.09 & 13.98 & $10 \cdot 41$ & $14 \cdot 15$ & - & - \\
\hline $\mathrm{CaO}$ & $5 \cdot 01$ & $21 \cdot 59$ & $19 \cdot 10$ & 21.85 & $0 \cdot 30$ & - \\
\hline $\mathrm{K}_{2} \mathrm{O}$ & 1.88 & - & 0.09 & - & - & - \\
\hline $\mathrm{Na}_{2} \mathrm{O}$ & 6.97 & - & 1.82 & - & - & - \\
\hline $\mathrm{P}_{2} \mathrm{O}_{5}$ & - & - & - & - & - & - \\
\hline \multirow[t]{2}{*}{ Total } & $98 \cdot 26$ & $98 \cdot 80$ & $98 \cdot 27$ & 99.99 & \multirow{2}{*}{\multicolumn{2}{|c|}{$\begin{array}{l}\text { No. of ions on the } \\
\text { basis of 4-oxygen } \\
\text { for titano-magnetite }\end{array}$}} \\
\hline & \multicolumn{2}{|c|}{$\begin{array}{l}\text { No of ions on the } \\
\text { basis of 8-oxygen }\end{array}$} & \multicolumn{2}{|c|}{$\begin{array}{l}\text { No. of ions on the } \\
\text { basis of 6-oxygen }\end{array}$} & & \\
\hline $\mathrm{Si}$ & $2 \cdot 75$ & 1.90 & 1.88 & 1.90 & 0.01 & - \\
\hline $\mathrm{Ti}$ & 0.01 & 0.04 & 0.03 & 0.04 & 0.87 & 0.87 \\
\hline $\mathrm{Al}$ & 1.25 & $0 \cdot 11$ & 0.31 & 0.11 & 0.08 & 0.08 \\
\hline $\mathrm{Cr}$ & - & 0.01 & 0.01 & $0-01$ & - & 0.01 \\
\hline $\mathrm{Fe}$ & 0.01 & 0.27 & 0.26 & 0.27 & 2.06 & 2.09 \\
\hline Mn & - & 0.01 & 0.01 & - & 0.05 & 0.05 \\
\hline $\mathrm{Mg}$ & - & 0.79 & 0.59 & 0.79 & - & - \\
\hline $\mathrm{Ca}$ & 0.24 & 0.87 & 0.78 & 0.87 & 0.01 & - \\
\hline K & 0.11 & - & - & - & - & - \\
\hline $\mathrm{Na}$ & 0.61 & - & 0.13 & - & $\begin{array}{l}\text { Oxide } T_{i} \text {-mgt } \\
\text { phase }\end{array}$ & Ti-mgt \\
\hline
\end{tabular}

*mph $=$ micro phenocryst

*Partial conversion of $\mathrm{Fe}^{2+}$ to $\mathrm{Fe}^{3+}$ (related to formation of magnetite) was not made. 
Table 1b. Chemical compositions of the rock samples'(Analyst--A K Gupta).

\begin{tabular}{lrr} 
& $\begin{array}{c}\text { Chemical Composition } \\
\text { D-81 }\end{array}$ & D-159 \\
\hline $\mathrm{SiO}_{2}$ & $45 \cdot 21$ & 50.09 \\
$\mathrm{TiO}_{2}$ & $2 \cdot 25$ & 2.68 \\
$\mathrm{Al}_{2} \mathrm{O}_{3}$ & $10 \cdot 39$ & $14 \cdot 27$ \\
$\mathrm{Fe}_{2} \mathrm{O}_{3}$ & 12.47 & $12 \cdot 47$ \\
(total iron) & & \\
$\mathrm{MnO}$ & $0 \cdot 19$ & 0.18 \\
$\mathrm{MgO}$ & 13.52 & $5 \cdot 70$ \\
$\mathrm{CaO}$ & 12.26 & 9.60 \\
$\mathrm{Na}{ }_{2} \mathrm{O}$ & 1.27 & 2.66 \\
$\mathrm{~K}_{2} \mathrm{O}$ & 0.57 & 1.16 \\
$\mathrm{P}_{2} \mathrm{O}_{5}$ & $0 \cdot 21$ & 0.24 \\
Loss & 1.90 & 1.04 \\
Total & $100 \cdot 24$ & 100.09 \\
\hline
\end{tabular}

Table 1c. Normative compositions of the rock samples corresponding to table $1 \mathrm{~b}$.

\begin{tabular}{lcc}
\hline & $\begin{array}{c}\text { Normative composition } \\
\text { D-81 }\end{array}$ & D-159 \\
\hline $\mathrm{Q}$ & - & 0.77 \\
$\mathrm{Or}$ & 3.37 & 6.85 \\
$\mathrm{Ab}$ & 10.75 & 22.51 \\
$\mathrm{An}$ & 20.97 & 23.57 \\
$\mathrm{Ne}$ & - & - \\
$\mathrm{Di}$ & 30.93 & 18.67 \\
$\mathrm{Hy}$ & 4.18 & 17.82 \\
$\mathrm{Ol}$ & 19.62 & - \\
$\mathrm{Ml}$ & 2.71 & 2.15 \\
$\mathrm{Tl}$ & 4.27 & 5.09 \\
$\mathrm{Ap}$ & 0.50 & 0.52 \\
$\mathrm{Di}$ & 14.11 & 30.13 \\
\hline
\end{tabular}

grained with fairly well-crystallized groundmass of plagioclase, pyroxene and opaque minerals. Plagioclase, olivine and two pyroxenes are present as phenocrysts and microphenocrysts. Olivine has infrequently a remnant core, mantled by orthopyroxenes. Pyroxenes are present as cumulates. The samples were crushed to 200 mesh for experimental studies.

As mentioned by Singh et al (1990), our calibration shows a large variation in temperature near the centre and the periphery of the cell. Hence the sample was placed exactly at the centre to avoid temperature variation and our temperature measurement was estimated to be accurate to $\pm 10^{\circ} \mathrm{C}$. Pressure was considered to be correct to $\pm 1 \mathrm{~kb}$.

The following criteria, suggested by Schairer (1959), were used to test the attainment of equilibrium:

(i) the absence of corroded crystals,

(ii) agreement of data with that of the nearby mixtures, 
Table 2. Results of experimental runs under dry conditions on sample D-81 and sample D-159.

\begin{tabular}{|c|c|c|c|}
\hline \multirow{2}{*}{$\begin{array}{l}\text { Run No./ } \\
\text { Sample No. } \\
\text { D-81 }\end{array}$} & \multicolumn{2}{|c|}{$\begin{array}{l}\text { Conditions of the } \\
\text { run }\end{array}$} & \multirow[b]{2}{*}{$\begin{array}{l}\text { Phases present, as indicated by microscopic and/or X-ray } \\
\text { diffraction studies }\end{array}$} \\
\hline & $\begin{array}{l}\text { Pressure } \\
\quad(\mathrm{kb})\end{array}$ & $\begin{array}{l}\text { Temp. } \\
\left({ }^{\circ} \mathrm{C}\right)\end{array}$ & \\
\hline 1 & 20 & 1200 & $\mathrm{Pl}+\mathrm{Cpx}+\mathrm{Mt}+$ Lots of $\mathrm{Gl}$ \\
\hline 2 & 20 & 1300 & $\mathrm{Pl}+\mathrm{Cpx}+\mathrm{Mt}+$ Lots of $\mathrm{Gl}$ \\
\hline 3 & 25 & 1250 & $\begin{array}{l}\mathrm{Ga}+\mathrm{Cpx}+\mathrm{Pl}+\mathrm{Mt}+\mathrm{quartz}(?)(\text { low relief)* }+ \text { Quench } \\
\mathrm{Cpx}+\mathrm{Gl} \text { (very rare) }\end{array}$ \\
\hline 4 & 30 & 1200 & $\mathrm{Ga}+\mathrm{Cpx}+\mathrm{Pl}+\mathrm{Mt}+$ quartz (?) (low relief)* Trace of $\mathrm{Gl}$ \\
\hline 5 & 30 & 1300 & $\mathrm{Ga}+\mathrm{Cpx}+\mathrm{Pl}+\mathrm{Mt}+$ Small amounts of $\mathrm{Gl}$ \\
\hline 6 & 35 & 1200 & $\mathrm{Ga}+\mathrm{Cpx}+\mathrm{Mt}+$ quartz (low birefringence) $*+\mathrm{No}^{*} \mathrm{Gl}$ \\
\hline 7 & 35 & 1300 & $\begin{array}{l}\mathrm{Ga}+\mathrm{Cpx}+\mathrm{Mt}+\text { quatz* (low birefringence) phase + Trace } \\
\text { of } \mathrm{Gl}\end{array}$ \\
\hline 8 & 40 & 1200 & $\mathrm{Ga}+\mathrm{Cpx}+\mathrm{Mt}+$ silica (coesite?)* + No Gl \\
\hline 9 & 40 & 1300 & $\mathrm{Ga}+\mathrm{Cpx}+\mathrm{Mt}+$ Quench $\mathrm{Cpx}+$ Small amounts of Gl \\
\hline \multicolumn{4}{|l|}{ D-159 } \\
\hline 1 & 20 & 1200 & $\mathrm{Pl}+\mathrm{Cpx}+\mathrm{Mt}+\mathrm{Gl}$ \\
\hline 2 & 30 & 1200 & $\mathrm{Ga}+\mathrm{Pl}+\mathrm{Cpx}+\mathrm{Mt}+\mathrm{Gl}$ \\
\hline 3 & 30 & 1300 & $\mathrm{Ga}+\mathrm{Pl}+$ Quench $\mathrm{Cpx}+\mathrm{Mt}+$ Lots of $\mathrm{Gl}$ \\
\hline 4 & 35 & 1250 & $\mathrm{Ga}+\mathrm{Cpx}+\mathrm{Mt}+$ Lots of $\mathrm{Gl}$ \\
\hline 5 & 40 & 1200 & $\mathrm{Ga}+\mathrm{Cpx}+\mathrm{Mt}+\mathrm{Qtz}$ \\
\hline 6 & 40 & 1300 & $\mathrm{Ga}+\mathrm{Cpx}+\mathrm{Mt}$ \\
\hline
\end{tabular}

**Abbreviation: $\mathrm{Pl}=$ plagioclase $\mathrm{Cpx}=$ clinopyroxene; $\mathrm{Ga}=$ garnet; $\mathrm{Mt}=$ magnetite; $\mathrm{Gl}=$ glass; $\mathrm{Qtz}=$ quartz; ${ }^{*}$ present in small amount; cannot be detected by $\mathrm{X}$-ray. For brevity all runs are not included.

(iii) consistency of the results at the same temperature for different lengths of time, (iv) good distribution of the phases in the glass.

After equilibration, $X$-ray diffraction $(\mathrm{CuK} \alpha)$ and optical studies were made to identify different phases. They are mainly clinopyroxene, plagioclase, quartz, magnetite, garnet and glass (table 2).

Pyroxene occurs at pale green stout prismatic crystals with inclined extinction. It has slightly lower R.I. than pure diopside. It could be identified by its reflections: $(22 \overline{1}),(20 \overline{2}),(31 \overline{1}),(310),(220)$. Omphacitic pyroxene was obtained at higher pressures (35 and $40 \mathrm{~kb})$.

Plagioclase occurs as needle-shaped or lath-shaped crystals with low birefringence. It was identified by its following reflections: (204), (004), (202), (200), (040).

Quartz appears as crystals of low birefringence with irregular fractures and no cleavage. It could be identified by its following reflections: (101), (100), (112).

Garnet occurs as euhedral isotropic crystals of greenish grey colour. It is characterized by high relief and rough surface. It could be identified by the following reflections: (420), (400), (332), (422), (431).

Magnetite occurs as opaque, euhedral to anhedral, isometric crystals. 


\section{Results and discussion}

Our experimental results are summarized in figures 1 and 2 and table 2.

On the basis of the appearance of garnet and the disappearance of plagioclase, the boundaries for basalt-eclogite phase transition were plotted. The P-T diagrams of figures 1 and 2 can be divided in terms of three areas: the basalt region (below AB or EF); the transition zone (between $\mathrm{AB}$ and $\mathrm{CD}$ or EF and $\mathrm{GH}$ ) and the eclogite region (above $\mathrm{CD}$ or $\mathrm{GH}$ ).

The basaltic field (at low pressure) is a field of $\mathrm{Cpx}+\mathrm{Pl}+\mathrm{Mt}$. It must be noted that the original starting material, which crystallized at low pressure, contained olivine. However, it is absent in our run products at high pressure. The amount of olivine, originally present, may be related to the incongruent melting of orthopyroxene. Under high pressure, as the incongruent melting is eliminated, orthopyroxene should precipitate. Crystallization of more orthopyroxene at high pressure might be related to the following alternative scheme: In our experimental studies, oxygen fugacity was not controlled and under a slightly oxidized condition, olivine crystallized to form magnetite and orthopyroxene:

$$
\underset{\text { Olivine }}{\left(3 \mathrm{Mg}_{2} \mathrm{SiO}_{4}+3 \mathrm{Fe}_{2} \mathrm{SiO}_{4}\right)}+\underset{\mathrm{O}_{2}}{\mathrm{O}_{2}} \rightarrow \underset{\text { Enstatite magnetite }}{6 \mathrm{MgSiO}_{3}}+2 \mathrm{Fe}_{3} \mathrm{O}_{4}
$$

(Muir and Scoon 1957)

Reference to the study of Kushiro (1969) suggests that the $10-15 \%$ orthopyroxene at $20 \mathrm{~kb}$ can be incorporated by clinopyroxene at the temperature range of $1200-1400^{\circ} \mathrm{C}$. This explains the absence of orthopyroxene and olivine, and the presence of magnetite. The latter was, however, originally present in small amounts.

The transition zone is marked by a decrease in the amount of plagioclase and the appearance of garnet. Orthopyroxene present in the bulk rock should react with

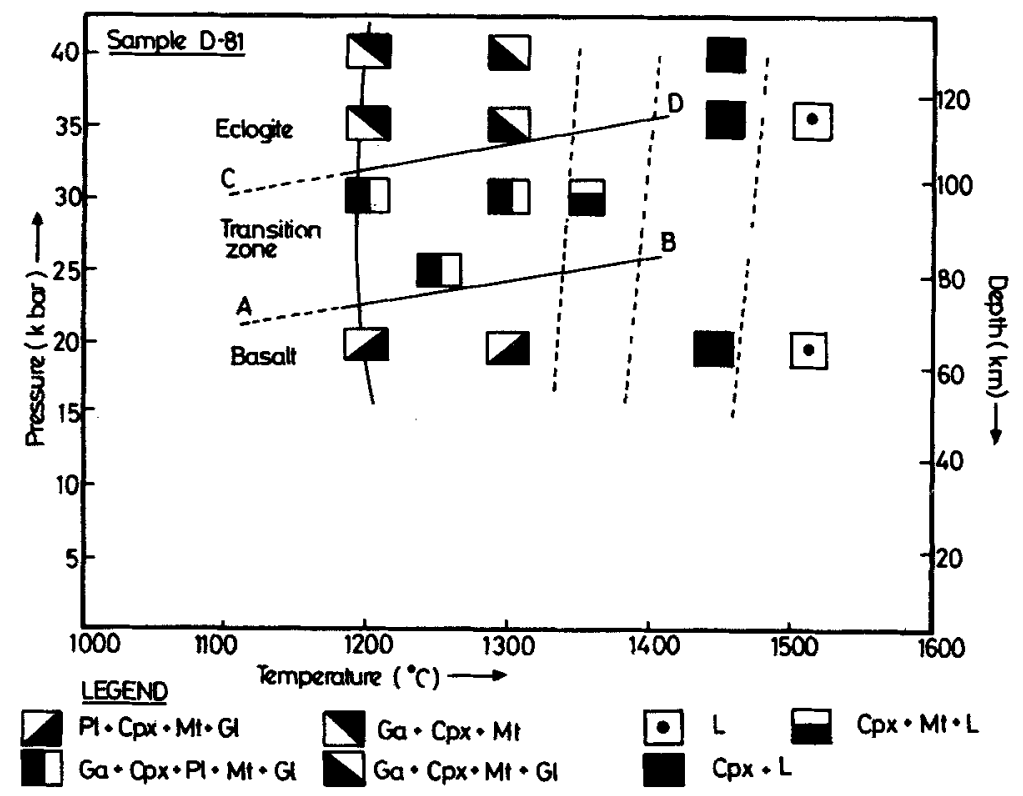

Figure 1. P-T diagram related to conversion of tholeiitic picrite to eclogite. 


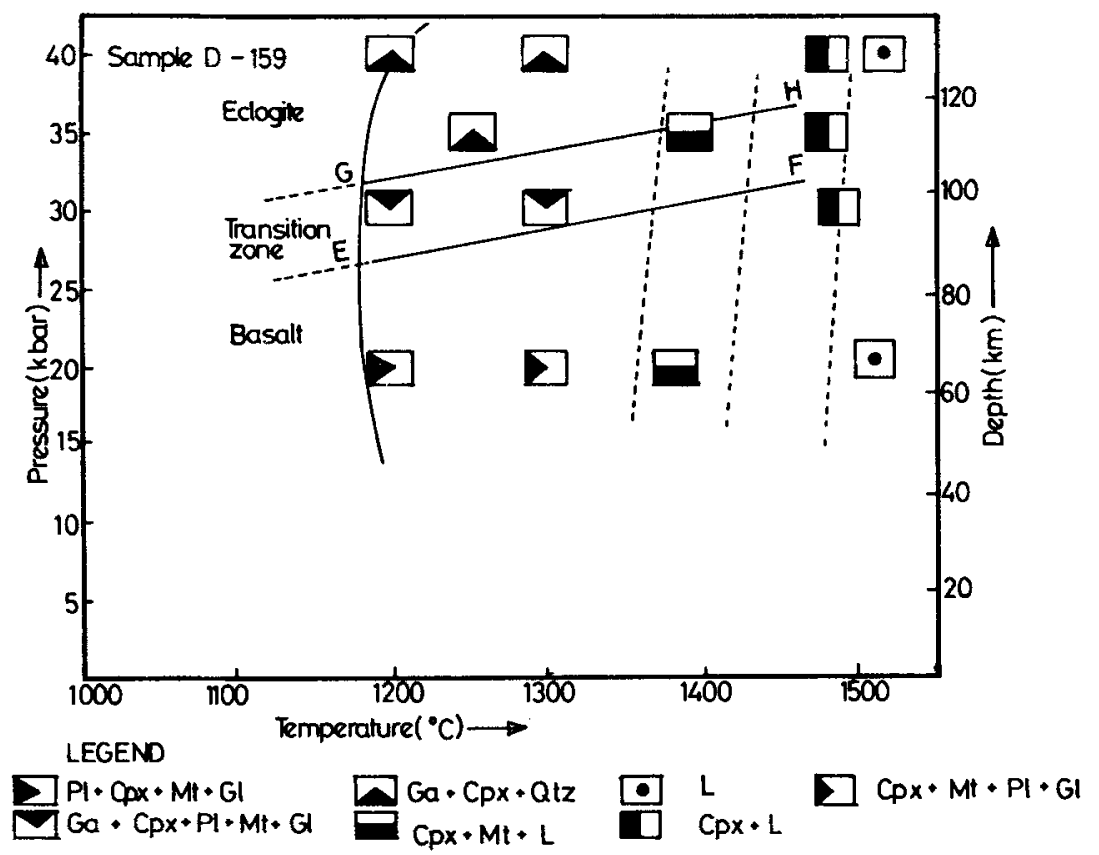

Figure 2. P-T diagram related to conversion of olivine tholeite to eclogite.

plagioclase under higher pressure to form garnet (Ito and Kennedy 1967; Kushiro and Yoder 1966). The upper and lower P-T limits of the transition zone are almost consistent with the results of previous workers, related to basalt-eclogite conversion. A study of Kushiro (1968) on the system Di-Ab-An (the haplobasalt system Bowen 1915) up to $35 \mathrm{~kb}$ suggests that plagioclase along with omphacitic pyroxene and garnet can persist up to a depth of about $90-100 \mathrm{~km}$. The albite and anorthite ratio also should control the stability of plagioclase and the appearance of garnet (Hays 1966; Hariya and Kennedy 1968). The presence of a significant amount of olivine in basaltic starting material is necessary for the appearance of spinel (Kushiro and Yoder 1966; Kushiro 1968; Ito and Kennedy 1967). The P-T range of spinel-bearing transition zone should therefore depend on the olivine content. In the eclogite region, plagioclase disappears completely and the assemblage is $\mathrm{Ga}+\mathrm{Cpx}+\mathrm{Mt}$. The proportion of garnet to clinopyroxene seems to increase with increasing pressure, and is estimated to be almost up to $30 \mathrm{vol} \%$. The presence of garnet should control the density variation, leading to a change in seismic velocity in the lithosphere.

Near the solidus the reaction curves for the appearance of garnet and disappearance of anorthite in the system $\mathrm{CaO}-\mathrm{MgO}-\mathrm{Al}_{2} \mathrm{O}_{3}-\mathrm{SiO}_{2}$ (Kushiro and Yoder 1966) are almost consistent with the P-T conditions for the conversion of basalt to ectogite, as noted in our study.

The extrapolation of the basalt-eclogite transition boundaries to lower temperatures has an appreciable uncertainty. The gradient of the phase transition zone is approximately $17 \mathrm{bar} /{ }^{\circ} \mathrm{C}$, which is only slightly different from that of Green and Ringwood's $21 \mathrm{bar} /{ }^{\circ} \mathrm{C}$. This gradient of $17 \mathrm{bar} /{ }^{\circ} \mathrm{C}$ is used to extrapolate the transition zone, as shown by the dashed lines in figures 1 and 2 . However, the last word has yet to be written on the position of the basalt-eclogite phase transition at low temperatures. 


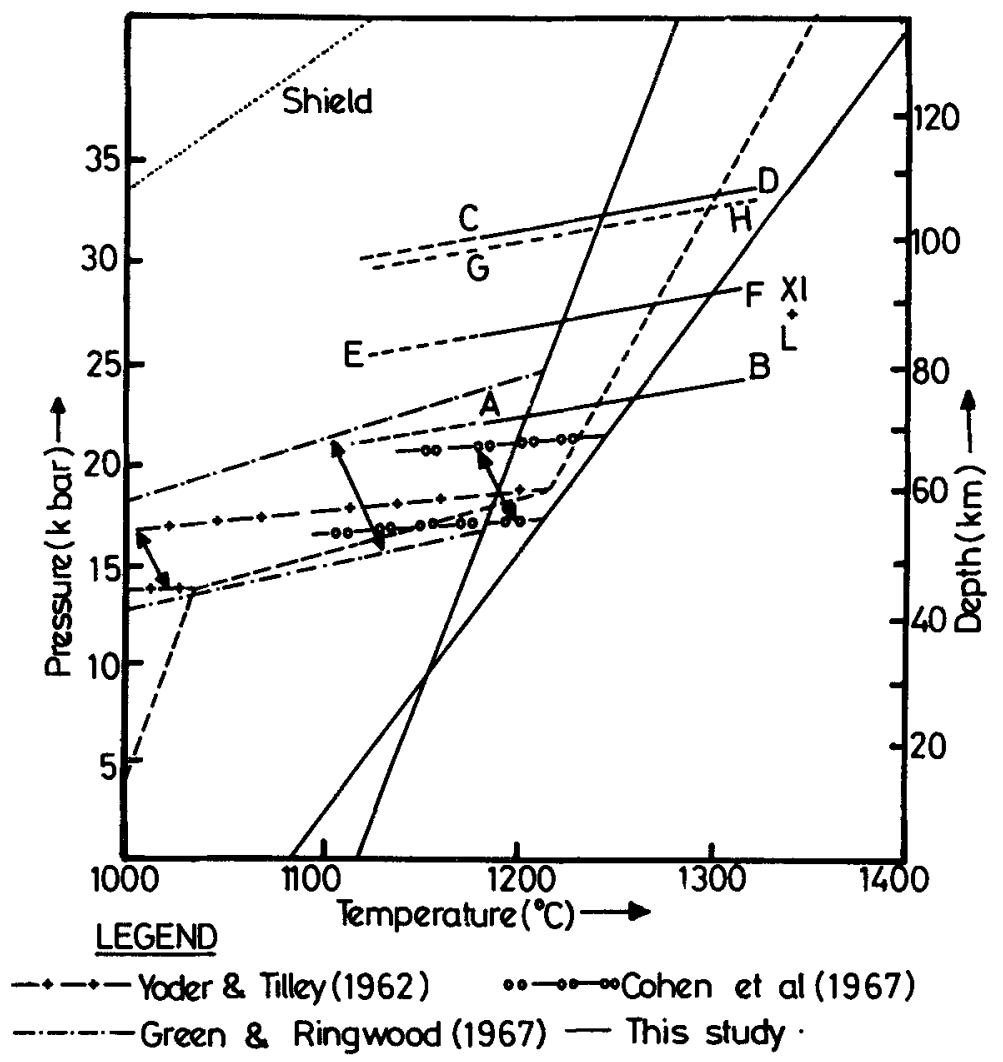

Figure 3. Comparative study of previous and present investigations on basalt-eclogite conversion.

For the position of the basalt-eclogite transition zone, the results of four investigators, based on experimental studies with natural rock compositions, are compared in figure 3. In the present study, at temperatures between $1000^{\circ} \mathrm{C}$ and $1300^{\circ} \mathrm{C}$, the elimination of plagioclase and appearance of garnet occur at higher pressures than that found by the other three workers. It could be due to the compositional differences in the starting material. The present study was carried out with tholeiitic picrite and olivine tholeiite, whereas Ringwood and Green (1966) and Green (1976) used quartz tholeiitic glass. Yoder and Tilley (1962) and Cohen etal (1967) performed their experiments on olivine tholeiite glass.

It is concluded that a voluminous amount of basaltic melt ascends through the fracture-system towards the crust, but a significant portion of this liquid crystallizes within the mantle as pockets of eclogite. It is known that at a given depth, the density of an eclogite is much higher than that of peridotite. Thus, eclogite with $20-30 \%$ garnet should cause a rise in the seismic velocity in the mantle material by approximately $2-3 \%$. The variation in the velocity-increase from place to place in the upper mantle, may be assumed to be due to the presence of different proportions of garnet within the eclogite. This would account for the increase in seismic velocity, as observed by Iyer et al 1989.

If our inference is correct then every region of flood basalts should be underlaid by a peridotitic mantle with pockets of eclogite. Thus both the flood basalts and the eclogites owe their genesis to the same parental liquid. 


\section{Acknowledgements}

We thank the Department of Science and Technology for providing funds (18(7)/81STP-II) that enabled us to complete this investigation. This paper is dedicated to the late Sir C V Raman, on the occasion of his birth centenary.

\section{References}

Bowen N L 1915 The crystallization of Haplobasaltic, Haplodioritic and related magmas; Am. J. Sci. 4 40 161-185

Cohen L M, Ito K and Kennedy G C 1967 Melting and phase relations in a hydrous basalt to $40 \mathrm{~kb}$; Am. J. Sci. $265475-518$

Green D H 1976 An experimental investigation of the gabbro to eclogite transformation and its petrological applications; Geochim. Cosmochim. Acta 31 767-883

Hays J F 1966 Lime-Alumina-Silica; Carnegie inst. Washington, Years. 65 235-239

Hariya Y and Kennedy G C 1968 Equilibrium study of anorthite under high pressure and high temperature; Am. J. Sci. 266 193-203

Ito $\mathrm{K}$ and Kennedy G C 1967 Melting and phase relations in a natural peridotite to $40 \mathrm{~kb}$; $\mathrm{Am}$. J. Sci. $265519-538$

Iyer H M Gaur V K, Rai S S, Ramesh D S, Rao C V R, Srinagesh D and Suryaprakasam K 1989 High velocity anomaly beneath the Deccan volcanic province: Evidence from seismic tomography; Proc. Indian Acad. Sci. (Earth and Planet. Sci.) 98 31-60

Kushiro I and Yoder H S Jr 1966 Anorthite-forsterite and anorthite-enstatite reactions and their bearing on the basalt-eclogite transformation; J. Petrol. 7 337-362

Kushiro I 1968 Compositions of magmas formed by partial zone melting of the earth's upper mantle; J. Geophys. Res. 73 619-634

Kushiro I 1969 Clinopyroxene solid solutions formed by reactions between diopside and plagioclase at high pressures; Mineral. Soc. Am., Spec. Pap. 2 179-191

Muir I D and Scoon J H 1957 Contributions to the petrology of Hawaiian basalts, 1 . The picrite basalts of Kilauea; Am. J. Sci, 255 241-53

Mukherjee P K 1986 Geochemistry and evolution of Pavagarh lava flows, Gujrat (unpublished Ph.D. thesis)

Ringwood A E and Green D H 1966 An experimental investigation of the gabbro-eclogite transformations and some geophysical implications; Tectonophysics 3 383-427

Schairer J F 1959 Physico-Chemical measurements at high temperatures. In Researches in Geochemisty (ed.) J O Bockris (Butterworths, London) p. 117

Singh P, Chopra R and Gupta A K 1990 Preliminary phase equilibria of the nepheline-diopside system under variable pressures (up to $28 \mathrm{~kb}$ ) and temperatures; Proc. Indian Acad. Sci. (Earth Planet Sci.) 99 pp. 49-55 (this volume)

Yoder H S and Tilley C E 1962 Origin of basalt magma: An experimental study of natural and synthetic systems; J. Petrol. 3 342-532 